\title{
Correction to: Paternal lineage affinity of the Malay subethnic and Orang Asli populations in Peninsular Malaysia
}

\author{
SyedHassan SharifahNany RahayuKarmilla ${ }^{1}$ Alwi R. Aedrianee ${ }^{2}$. \\ Abd Rashid Nur Haslindawaty ${ }^{1}$ - Abdullah Nur Azeelah ${ }^{1}$. \\ Sundararajulu Panneerchelvam ${ }^{1} \cdot$ Mohd Nor Norazmi $^{1} \cdot$ Zainuddin Zafarina $^{1,3}$
}

Published online: 13 November 2017

(C) Springer-Verlag GmbH Germany 2017

Correction to: Int J Legal Med (2017)

https://doi.org/10.1007/s00414-017-1697-0

The original version of this article contains an error. The Author Abd Rashid Nur Haslindawaty has been added as to the above author group as third author. The original article was corrected.

The online version of the original article can be found at https://oi.org/ 10.1007/s00414-017-1697-0

\footnotetext{
Zainuddin Zafarina

zafarina@usm.my

1 Human Identification/DNA Unit, School of Health Sciences, Universiti Sains Malaysia, Health Campus, 16150 Kubang Kerian, Kelantan, Malaysia

2 Department of Chemistry Malaysia, Jalan Abdul Samad, 80100 Johor Bahru, Johor, Malaysia

3 Analytical Biochemistry Research Centre (ABrC), Universiti Sains Malaysia, 11800 USM Penang, Malaysia
} 